\title{
DETERMINANTS OF ASSAULT ON FOOTBALL LEAGUE REFEREES DURING COMPEITIIONS IN NIGERIA
}

\author{
Danjuma Moudu Momoh, A, B, C, D, E Toyosi Olaseyo $0^{A, B, C, D, E}$ \\ Department of Human Kinetics and Health Education, Faculty of Education, Adekunle Ajasin University, Akungba-Akoko, Ondo State, Nigeria

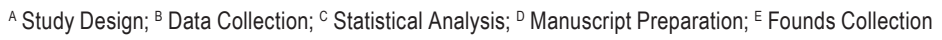 \\ Address for corpespondence: \\ Danjuma Moudu Momoh \\ Department of Human Kinetics and Health Education \\ Faculty of Education, Adekunle Ajasin University, Akungba-Akoko \\ Ondo State, Nigeria \\ E-mail: danjuma.momoh@aaua.edu.ng
}

\begin{abstract}
Ahstract The assault on referees is an act committed by an individual involved in a match such as players, substitutes, coaches, team officials or spectators against a referee that is of a violent or intimidating nature. This study, therefore, investigated the level of assault of referees in Nigeria's Premier Football League. The participants for the study consisted of two hundred and fifty (250) Nigerian Premier League elite referees, footballers, coaches, and spectators. The purposive sampling technique was used for the study to select the respondents. A structured questionnaire with validated and reliability value of 0.75 was used for data collection. The data was analyzed using the inferential statistics of Chi-square $\left(x^{2}\right)$ to test the research questions and hypotheses at 0.05 alpha levels. The three hypotheses of officiating, organization of the league and win at all cost tested, were all rejected. Consequently, some recommendations were made based on the findings of the study.
\end{abstract}

Key Worlls assault, competition, football, professionalism, violence

\section{Introduction}

Football has become a social phenomenon which brings people together attracting the attention of millions all over the world. Apart from being simply watched as a game, football is currently a vast commercial concern, global competition is intense, and the production and marketing sectors work in close conjunction on the sport (Collina, 2003).

The referee and match officials make up a crucial element in the game of football. Like them or not, it is through the diligence, professionalism and often hard work of these men and women, that football matches across the globe can take place. However, the individuals who are match officials are often the target of unnecessary and unruly taunts and abuse, because of the job that they have offered to do (Rainey, Hardy, 1999). Today, Football is 
the most popular sport in the world. It is the least expensive but the richest sport. It is the sport that people travel far-off distance to witness. It is the sport that caused wars between nations and bitter enemies very close friends. It is the sport in which passions can easily rise, fight can erupt, and a whole place can be destabilized (Smith, 2003). People often go to witness this sport with preconceived outcome of the match. When the result of the match is not as expected, the consequences would be extremely unpleasant. Thus, the pressure on referees to produce flawless performance is increasing and with media pundit attempting to create controversy, the spotlight is often cast upon the match referee (Morrison, 2002).

The vast financial dimension of football makes the effective conduct of the matches an important issue that moves way beyond being a simple event influencing only the football players, the managers, and the crowd (Wolfson, Neave, 2007). Developments in these huge markets determine the achievements or failures of the clubs and, at this point the performances of referees, who control the matches, are subject to much critical discussion.

Referees and match officials are special populations, and as such, it takes a special kind of individual to become a referee. Not only do they need to be physically fit and be able to keep up with play (Reilly, Gregson, 2006), they need to be able to cope with threats that are targeted towards them.

The responsibility of the football referee on the ground, in a sport that is sometimes watched by millions, even hundreds of millions, is huge. Additionally, the facts that proportion of people income going on sports increases, and sports share in the economy rises, and the incomes of referees have risen proportionately resisting in the perception that being a referee is an occupation in which people can earn a professional salary (Evans, Rowe, 2002)

Baldwin (2005) said refereeing in a sport like football requires not only knowledge, skills, and perseverance but also the ability to understand and predict people's behavior and courage. It is in this context that a football referee on the field has to behave like a psychologist to avoid being assaulted or battered. The sole job of the referee is to make sure that a game is played fairly and that all the players, coaches and associated personnel adhere to the rules of the game. The toughest job for referee is keeping players and coaches calm after a close call (Weinstein, 2003).

Refereeing is one of the hobbies that require the ability to make many decisions in a short period of time. Quick decisions must be at frequent intervals. Therefore, attention and concentration are vital and must be at a maximum level. The decisions made rapidly and in quick succession, are made under great pressure (Akanji, 2009). Accordingly, the effects of psychological and psychological states of referees, who have a great influence at every point in the game, must be taken into consideration at the present time. Referees should be capable of making the right decisions by keeping under control psychological elements such as anxiety, fear, and stress (Balch, Scott, 2007).

Collina (2003) posited that refereeing in sports competitions requires not only the possession of physical ability and knowledge about the rules of the game, but also the need for a display of physiological efficiency for the conduct of a successful performance during the game. In this sense, people who have a high previous experience of the same atmosphere, who have a high educational status, and who have played football before should be encouraged to conduct matches.

Football is a universal game which has a wide audience, and which is meant to be enjoyed by spectators, teams and match officials. Studies have shown that in Nigeria, violence and irresponsible behavior at match venues are regular occurrences. There are reports of match officials, especially referees, match commissioners even both the secret and open match assessors being manhandled by fans of the teams. 
The dangerous challenges posed by violence to the development of football in Nigeria should be the worry of lovers of the game because, football in Nigeria has lost its glorious reputation and fellowship due to violence, thuggery, assault on match officials and unfriendly atmosphere which have taken the center stage at venues of both professional and premiership league matches across the country.

Top-flight football referees in Nigeria are contending with a critical crisis. Two major incidents that concern them have threatened the 2018/2019 Nigeria Professional Football League season, which got underway on January 1 , 2019. On the opening weekend, ill-tempered fans went haywire in Jos, Plateau State and attacked match officials. A week later, the gory attacks by fans occurred again in Sagamu, Ogun State. For a sport that is trying to rediscover its halcyon days, these acts of violence are inimical to its growth. Not that violence had been totally absent from club football, but to witness bloody incidents on two consecutive match-days at the beginning of a season portends grave danger ahead. First, fans went berserk shortly after the match between the host team, Plateau United, and Ifeanyi Ubah FC ended goalless at the Rwang Pam Stadium in Jos. Alleging that the referees, led by Sam Agba, disallowed a goal, they stormed the pitch to attack the officials. Agba, who bore the brunt of the violence, oscillated between life and death after the barbaric attacks (Nigeria Punch, 2019)

Another ugly incident took occurred on $19^{\text {th }}$ January 2019 in another NPFL game in Sagamu. This time, it was at the Gateway Stadium where newly promoted Remo Stars drew 1-1 with visiting Insurance of Benin. Claiming that the referee, Bethel Nwanesi, and his assistants, A Nalado and B Salihu, disallowed their team's goal, they descended on them. Viral photos of the attacks in the social media were shocking: the officials' heads and back were covered in blood. This is criminality, not a show of support to a team. These fans should face the law (Nigeria Punch, 2019).

Lack of knowledge about what the rules say leads to absolute misunderstanding and misinterpretation of a referee's decision especially if the signals are against the home team what follows is pandemonium and crowd violence which will lead to assault of referees. Besides the fact that majority of Nigeria league fans are ignorant of the laws of the game, we witness bias officiating on the part of some referees.

This explains why it is very difficult for away teams to secure draws not to talk of a win. In most cases, officials of home teams either by intimidation or pre-match negotiation, illegally force referees to officiate in their favor not minding how their team plays, if a courageous or professionally minded referee refuses to follow the home team's line of action, he will eventually be descended upon especially when visiting teams escape with vital point(s).

Therefore, it can be said that the win at all cost mentality of some home teams is a major cause of referees' assault at some league centers. Most Nigerian football fans prefer to stay at home rather than go to league venues to watch local matches for the fear of insecurity. For instance, in the western world, people go to match venues to enjoy themselves and catch fun, but in Nigeria the reverse is the case, perhaps that is the main reason why the Nigerian league is unattractive and unexciting.

There was serious violence on Monday evening, June 10, at the Agege stadium in Lagos as fans of NPFL club Kano Pillars stormed the pitch at the ongoing Super Six playoff. The fans invaded the pitch in the encounter between Kano Pillars and Enugu Rangers which ended 1-1 as the Flying Antelopes kept their Champions League hopes alive. Kano Pillars' captain Rabiu Ali scored the first goal for his side via a superb free kick in the 58th minute, but Rangers came back into the game via a penalty ten minutes to final whistle. And before referee Adebimpe blew the final whistle, Kano Pillars had a free kick which was not scored and the match official ended the match afterwards. Rabiu Ali was then annoyed with how the referee ended the match claiming that the official did not allow them to 
play the full minutes. He was engaging in serious vituperation on the pitch against the referee before Kano Pillars fans got livid and decided to storm the pitch. They were seen holding all sort of harmful objects with the intention of harming the center referee, but the securities on ground were of help to the match official (Ibitoye, 2019)

The Nigeria premier league is the highest level of domestic football in Nigeria. The league was founded in 1972 with six teams. On Saturday 12th May 1990 at the Onikan Stadium Lagos, the league was re-christened the professional league with the goal to modernize the game and make clubs self-sufficient. Decrees 10 and 11 were used to codify the introduction of professional clubs which should be run as limited liability companies and each governed by a regularly constituted body.

The body is required to hold annual general meetings, present independently audited accounts, create youth or feeder teams, and own their own stadium within five years of registration with the league department (NFA, 1995). From 1999-2007, there was an end of season championship called the super four. The four teams from the groups would play a round robin mini league at a neutral ground to determine the league champion. After the 2006 competition, the league changed its calendar to more closely match the European regular season structure starting around August and ending around the month of May.

\section{Material and Methods}

\section{Study Area}

The study area covered five sport councils of southwest states of Nigeria (Lagos, Ogun, Oyo, Ondo, and Osun) The population of the study comprises of male and female referees, coaches, footballers, and spectators in the Nigeria football league in the South West of Nigeria.

\section{Sample and Sampling Techniques}

The random sampling technique was used to select 5 states out of the 6 states in the Southwest of Nigeria while purposive sampling technique was used to select 100 referees, 20 coaches, 100 footballers and 30 spectators making two hundred and fifty (250) participants who were the respondents for the study.

\section{Analysis and Discussion}

\section{Research Hypotheses}

\section{Hypothesis 1}

Table 1. Officiating of Football Referees will not be a significant determinant of Assault on Football referees in Nigeria Premier League

\begin{tabular}{ccccccc}
\hline Variable & Respondent & $X^{2}$ Cal & $X^{2}$ Crit. & Df & Sig. Level & Remark \\
\hline Officiating & 250 & 666.97 & 16.919 & 9 & 0.05 & Rejected \\
\hline
\end{tabular}

$P<0.05$

The result on Table 1 showed that the calculated value was higher than the $X^{2}$ table value, the null hypothesis was therefore rejected because of the revealing significance of officiating of football referees to assault on referees 
in the Nigeria Premier League. The way a game is handled by a referee can make or mar such match and also determine the outcome of the game. The result is in line with Inoyo (2011) who posited that good refereeing speeds up the flow of the game of football and inefficient refereeing spoils the enjoyment of the game for players, tacticians, and spectators. This also agreed with Arun (2004) who explained that a good referee should be consistent with his behavior in situations to remove any doubt about taking sides.

\section{Hypothesis 2}

Table 2. Organization of the league will not be a significant determinant of assault on football referees in Nigeria Premier League

\begin{tabular}{ccccccc}
\hline Variable & Respondent & $X^{2}$ Cal & $X^{2}$ Crit. & Df & Sig. Level & Remark \\
\hline Officiating & 250 & 114.91 & 16.919 & 9 & 0.05 & Rejected \\
\hline
\end{tabular}

$\mathrm{P}<0.05$.

Table 2 showed that the $\mathrm{X}^{2}$ calculated value was higher than the table value, therefore the null hypothesis was rejected, and organization of the league was found to be a significant determinant of assault on football referees in Nigeria Premier League.

Assault on football referees is equally galvanized through lack of organization on the team's part. This result is in line with Idowu (2009) who posited that most teams are not well organized structurally and they tend to put pressure on match officials. The result also agreed with Olaniyan (2011) that supporters clubs are not properly constituted and well organized with the football body thereby allowing hooligans to take laws into their own hands by assaulting match officials.

\section{Hypothesis 3}

Table 3. Win at all cost syndrome will not be a significant determinant of assault on football referees in Nigeria Premier League

\begin{tabular}{ccccccc}
\hline Variable & Respondent & $X^{2}$ Cal & $X^{2}$ Crit. & Df & Sig. Level & Remark \\
\hline Officiating & 250 & 400.38 & 16.919 & 9 & 0.05 & Rejected \\
\hline
\end{tabular}

$\mathrm{P}<0.05$.

Table 3 showed that $X^{2}$ calculated value was higher than the $X^{2}$ table value, therefore the null hypothesis was rejected because win at all cost syndrome was found to be significant in determining assault on football referees in Nigeria Premier League.

The result is in line with Ishola (2009) assertion that win at all cost syndrome is not a new development in the football league, and that home clubs in desperate attempts to win intimidate and harass football referees. The finding is also in line with Akanji (2009) position that clubs have been known to intimidate referees, rival teams and even supporters to win home matches at all cost. Generally, it was observed that the results of findings in this study was that officiating of football referees, knowledge of the laws of the game, security at match venues, organization of the league and win at all cost syndrome are all determinants of assault on football referees in Nigeria Premier League. 


\section{Conclusion}

The results of the data collected from the respondents showed that all the 3 null hypotheses tested were rejected, which implied that all the 3 variables tested were significant to the determinants of assault on football referees in Nigeria Premier League at 0.05 alpha level.

It was therefore concluded based on the findings of this study that:

1. Officiating of football referees will be a significant determinant of assault on football referees in Nigeria Premier League.

2. Organization of the league will be a significant determinant of assault on football referees in Nigeria Premier League.

3. Win at all cost syndrome will be a significant determinant of assault on football referees in Nigeria Premier League.

\section{Recommendations}

Based on the findings of this study and the conclusion drawn thereof the researchers therefore offer the following recommendations in anticipation that if implemented, will help to reduce if not eradicate football referee's assault in Nigeria Premier League.

1. Refresher courses for match officials and team administrators on laws of the game must be conducted regularly to update them on the laws governing football globally.

2. Football referees should be tested and found mentally and physically stable before allowing them to handle Premier League matches.

3. Football referees should be given matches to handle based on their competence and knowledge.

4. Football referees should be encouraged to make refereeing a hobby and not a full-time profession so as to curb any form of inducement from teams or administrators of clubs.

5. Supporters clubs of teams should be properly registered and accredited for proper monitoring and also curb the act of hooligans pretending to be supporters of league clubs thereby causing assault on referees at match venues.

6. The Nigeria Premier league should not encourage home teams to pay referees allowances.

7. The Nigeria Premier League should schedule matches before the start of the season and strictly adhere to the fixtures as planned.

\section{References}

Akanji, J.J. (2009). The League for the highest bidder. Weekend Soccer Star, 14.03.09.

Arun, S. (2004). Game, Set and Client Match. Media Asia, May 9, 28-29.

Balch, M.C., Scott, D. (2007). Contrary to popular belief refs are people too. Personality and perceptions of officials. Journal of Sport Behaviour, 30 (1), 3-20.

Baldwin, C. (2005). Field Research Notes. Sydney.

Collina, P. (2003). The rules of the game. London: Macmillan.

Evans, R., Rowe, M. (2002). For club and country: Taking Football Disorder Abroad. Journal of Soccer and Society, 3 (1), 37-53.

Ibitoye, S. (2019). Violence erupts in Lagos as Kano Pillars fans invade the pitch, attack referee. Genesis Media online (10.04.2020).

Idowu, N. (2009). Problem of Sport Federations. Retrieved from: www. playthegame.org. 
Inoyo, J. (2011). Laws of the game. Nigeria Football Referees Magazine, June, 16-17.

Inoyo, J. (2011). The Role of Psychology in Refereeing. Nigeria Football Referees Magazine, 24-28.

Ishola, W. (2009). Corruption bane of sport development in Nigeria. Retrieved from: www.nigeriamuse.com (10.10.2017).

Morrison, E. (2002) Football union elite referee development manager. Paper presented at inaugural elite referee union conference, Huddersfield, UK.

Nigeria Football Association (1995). Annual general meeting year guide. Lagos.

Nigeria Punch (2019). Attacks on football referees, inimical. Nigeria Punch online (accessed on 20.03.2020).

Olaniyan, O. (2011). Communication in refereeing before, during and after the match. Nigeria Football Referees Magazine, 14-15.

Rainey, D., Hardy, L. (1999). Sources of Stress, burnout and intention to terminate among referees. Journal of Sports Sciences, 17 , 797-806.

Reilly, T., Gregson, W. (2005). Special populations: The referee and assistant referee. Journal of Sports Sciences, 24 (7), $795-801$.

Smith, R. (2003). Towards a cognitive - affective model of athletic burnout. Journal of sport psychology, 8, 36-50.

Weinstein, M. (2003). Physiological load imposed on elite soccer referees during actual match play. Journal of Sports Medicine and Physical Fitness, 41 (1), 27-32.

Wolfson, S., Neave, N. (2007). Coping under pressure. cognitive strategies for maintaining confidence among soccer referees. Journal of Sports Behaviour, 30 (2), 232-247.

Cite this anticle as: Momoh, D.M., Olaseyo, T. (2021). Determinants of Assault on Football League Referees during Competitions in Nigeria. Central European Journal of Sport Sciences and Medicine, 1 (33), 127-133. DOI: 10.18276/cej.2021.1-12. 